\title{
Bone and Connective Tissue Physiology
}

National Cancer Institute

\section{Source}

National Cancer Institute. Bone and Connective Tissue Physiology. NCI Thesaurus. Code C18661.

Biological studies that combine molecular, cellular, and biochemical principles to understand the physiology of bone and connective tissues. 